\title{
Beyond the vulnerability/resilience dichotomy: Perceptions of and responses to the climate crisis on Emau, Vanuatu
}

\author{
Sophie Ruehr \\ Department of Environmental Science, Policy and Management, University of California \\ Berkeley, Berkeley \\ sophie ruehr@berkeley.edu
}

\begin{abstract}
In Vanuatu, a South Pacific island nation, the effects of climate change pose new challenges for low-lying coastal communities. This study explores how one village on Emau, an island offshore of capital island Efate, has developed several overlapping strategies to manage climate change impacts, including drought and sea level rise. Informants reveal their perceptions of changing environmental baselines and how socio-economic processes, including population growth, cultural loss, and limited access to cash incomes, have shaped the community's response. Informants describe four climate adaptation strategies: 1) expanding access to cash income through seasonal or urban labor migration; 2) leveraging international expertise and funding to meet their goals; 3) developing hybrid forms of traditional practices and contemporary ideology to preserve environmental knowledge; and 4) performing physical and emotional labor to preserve and remain on their land. These strategies span oceans and cross international borders, refuting narratives of islands' being 'isolated' from the rest of the world and passive 'victims' of climate change. Contextualizing perceptions of and responses to environmental change provides critical nuance to the resilience/vulnerability framework, which alone obscures ongoing political, social and economic processes on islands.
\end{abstract}

Keywords: adaptation, climate change, islands, resilience, Small Island Developing States (SIDS), Vanuatu, vulnerability

https://doi.org/10.24043/isj.151 • Received June 2020, Early access November 2020

(C) Island Studies Journal, 2022

\section{Introduction}

The climate crisis has arrived. Environmental baselines are changing at unprecedented rates, especially in the tropics, which are experiencing the greatest increases in flooding frequency (Vitousek et al., 2017) and cyclone intensity. Migration is often considered an inevitable solution to the climate crisis in small island developing states (SIDS). SIDS are depicted as isolated and lacking in natural resources (Hau'ofa, 1994), and island communities are painted as passive 'victims' of the climate crisis without the capacity to adapt in place (Walshe \& Stanicoff, 2018). This "eco-colonial" narrative from the Global North (Farbotko, 2010, p. 
47) fails to consider existing resiliency in island communities and presupposes islanders' future status as climate refugees (Farbotko \& Lazrus, 2012).

Several studies (Jamero et al., 2017; Perumal, 2018; Esteban et al., 2019) have documented Pacific island communities' determination to remain in place despite risks posed by climate change. This paper considers the overlapping strategies of one community in Vanuatu, an 'aquapelago' of mountainous volcanic islands in the South Pacific (Hayward, 2012), to manage climate change effects, either by adapting in place or continuing to protect land from safer homes uphill. Land is a central pillar of kastom (pre-European contact knowledge, culture, or history) in Vanuatu, or "the web of life that holds together custom, culture, history and beliefs of each person in a community" (Simo \& Naupa, 2005, p. 21). Therefore, Ni-Vanuatu (as people from Vanuatu call themselves) consider relocating or migrating only as a last resort, as documented by Perumal (2018). However, as Westoby et al. (2020) found, 'community-based' adaptation projects implemented by outsider 'experts' in Vanuatu fail long term due to lack of local ownership in these projects. The authors concluded that adaptation projects in Vanuatu should prioritize local leadership and acknowledge that islanders are the best planners for their futures (Westoby et al., 2020).

This study explores how one village on Emau, an island in Vanuatu's central Shefa Province, is implementing overlapping strategies to manage the effects of climate change. The paper begins by discussing informants' perceptions of environmental change on Emau in relation to other concerns, including cultural loss, population growth, and limited access to cash incomes. The paper then describes four strategies the community is implementing: 1) migrating to work in urban centers or participate in seasonal labor schemes to supplement incomes and build infrastructure uphill; 2) leveraging international aid and development funding to suit their visions for the future, including tourism industry development; 3) revitalizing kastom practices by inscribing traditional environmental knowledge within contemporary religious practice; and 4) performing physical and emotional labor to maintain and remain on ancestral land. The paper concludes that future studies should focus on perceptions of and responses to climate change instead of the vulnerability/resilience framework, as this dichotomy does not accurately represent the reality of climate change on Emau.

\section{Field site}

Vanuatu is located in the South Pacific, approximately 900 kilometers west of Fiji. It comprises over 80 islands, spanning 860 kilometers northwest to southeast in a Y-formation, with a total land area of $12,200 \mathrm{~km}^{2}$ and over $2,500 \mathrm{~km}$ of coastline (see Figure 1a). Vanuatu has population of approximately 288,000 with a growth rate of $1.7 \%$ as of July 2020 (Central Intelligence Agency, 2020). Described as nation-states, each island of Vanuatu is unique, with various cultural practices and kastom beliefs that vary widely, even on a single island (Franç,ois et al., 2015).

The field site, Emau island, is home to approximately 600 people in total, distributed among six villages. Kinship ties are strong; children often marry between villages, creating matrilineal networks that are maintained by weekly visits or island-wide events. Emau has a long history (since the early 1900s) of residents' working in Port Vila, the capital city on neighboring island Efate. Today, many families live divided between Emau and Port Vila, commuting weekly from the city to the island or vice-versa to visit relatives and maintain 
community ties (see Figure 1b). Residents of Emau speak Bislama, a creole and one of the national languages of Vanuatu. Emau residents also speak an endemic language distinct from French, English, and Bislama (as described by Facey [1988]).

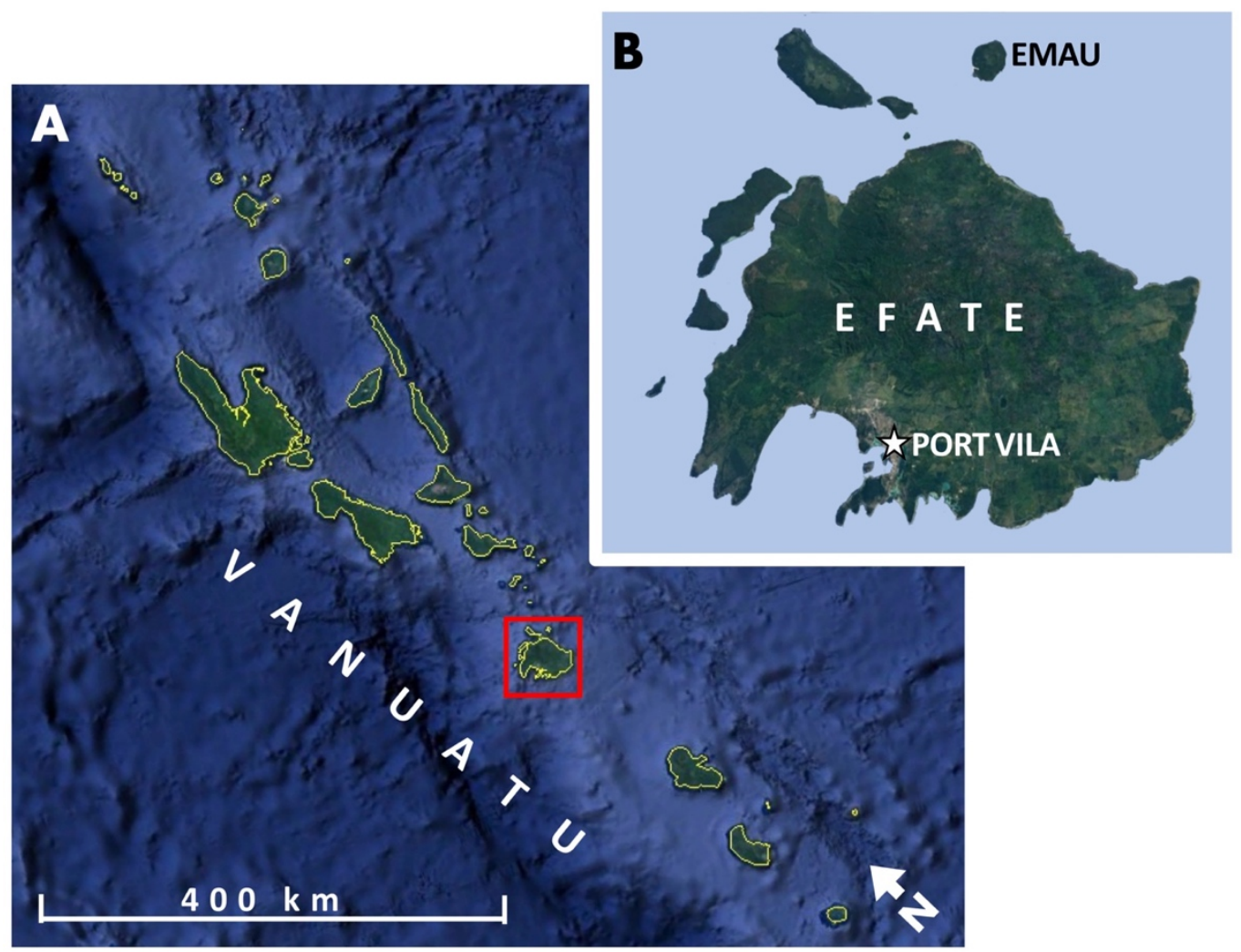

Figure 1. Maps of (a) Vanuatu and (b) Efate, the capital island, with its offshore islands, including Emau, to the north. Source: Map data: Google. Images: Landsat/Copernicus.

Marou village, where the majority of field work was conducted, is located on the west coast of Emau and has a population of 300. The town occupies a low-lying peninsula between the sea and a coastal lagoon (see Figure 2a). In the heart of the village, the peninsula is 80 meters in width, and its elevation does not exceed one meter (see Figure 2b). Most informants are also subsistence farmers, growing banana, taro, manioc, yam, coconuts, and aelan cabis (a dark leafy green) in gardens uphill. Although cash economy is limited on the island, there are several small businesses run from homes and a cooperative. In recent years, international visitors to Emau have included PeaceCorps volunteers, other aid workers, scientists, and tourists. 


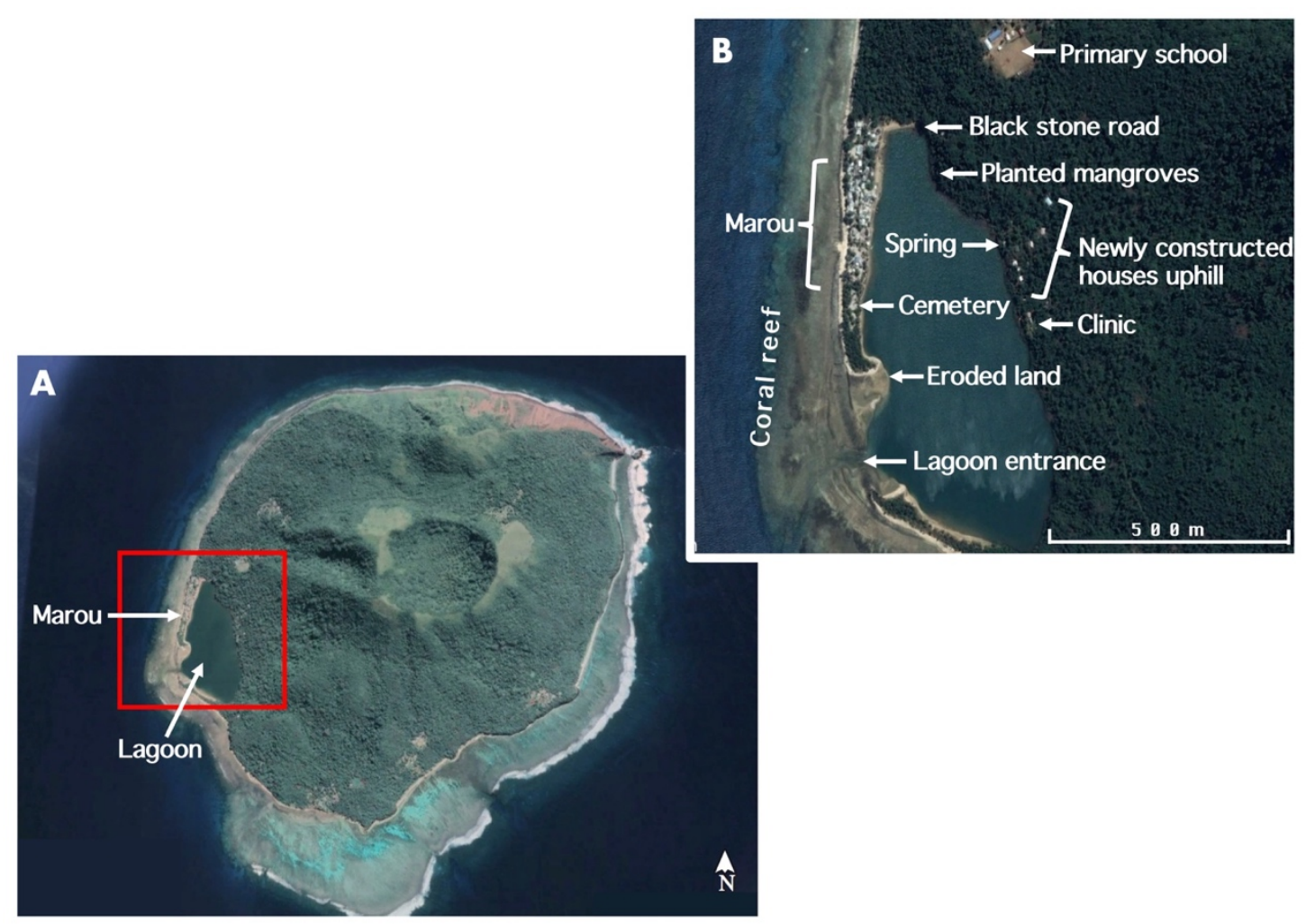

Figure 2. Maps of (a) Emau island and (b) Marou village, with important sites labelled. Source: Map data: Google. Images: CNES/Airbus.

\subsection{Theoretical framework}

The climate vulnerability/resilience framework is a powerful rhetorical force in the South Pacific. Islanders are considered both victims and heroes of climate change, and international development funding is often directed towards SIDS specifically for climate resilience projects (Baldacchino, 2018). However, the vulnerability/resilience dichotomy has recently been subjected to critique. As Cameron (2012) describes, this framework overlooks historic and contemporary power relations between Indigenous peoples and outside actors such as other countries or corporations. By limiting Indigenous communities to the sphere of the 'local' and 'traditional' — and in the context of an archipelago, isolated from the outside world — research regarding environmental 'vulnerability' is liable to obscure the power relations that shape daily life for Indigenous peoples. Indeed, coping with the climate crisis is more contingent upon power relations than weather patterns (Farbotko \& Lazrus, 2012).

As Kelman (2020) has shown, vulnerability and resilience exist within a dialectic relationship. The two often influence and result from one another. Conceiving of vulnerability and resilience as problem and solution conceals their dialectic nature, creating overly simplistic narratives of SIDS. Furthermore, overemphasizing the effects of climate change in SIDS obscures other concerns. Since international development funding is tied to climate-related projects, SIDS often must refer to the climate crisis to secure resources for any project, even if unrelated to climate change (Baldacchino, 2018). This overemphasis on climate vulnerability/resilience distorts the reality of life in SIDS.

Finally, resultant development programming - one of many modern-day "civilizing missions" on islands (Baldacchino, 2008, p. 39) - provides blanket solutions to complex 
problems without addressing underlying inequality (Li, 2014). Development projects frequently benefit foreign political strategies rather than addressing the root causes of environmental vulnerability: alienation and power imbalances (Manuel-Navarrete, 2010). Most development projects in Vanuatu expressly introduce outsider norms, even if these norms conflict with existing social structures and kastom values within Vanuatu (Varrall, 2019).

Climate change adaptation strategies in Oceania must be considered within the particular socio-economic and political context of individual communities, as each island is uniquely positioned within geopolitical processes that present diverse options and intersections (Karides, 2017; Walshe \& Stancioff, 2018). This paper builds on previous literature by providing specific examples of the dialectic nature of resilience and vulnerability. Perceptions of and responses to climate change provide nuance to this dichotomy, which alone does not accurately capture the reality of the climate crisis on SIDS.

\subsection{Methodology and analysis}

Several methodologies were employed over a series of four week-long visits to Emau. I presented the intentions of my research during a 3-hour long workshop, attended primarily by community elders, in January 2019. During subsequent visits, I conducted semi-structured interviews, which were recorded and transcribed, based on a questionnaire translated into Bislama, following Bernard (2006). The order and content of questions varied depending on the conversation. Data were also collected via informal interviews and participant observation. My methods drew on Vaioleti's (2006) description of talanoa discourse (an Oceania-derived conversation style rooted in reciprocity and compromise) and the Vanuatu-specific version of conversation, storian, that Warrick (2009) outlines. Landmarks around the village were also used to organize information about important events and historical periods. Informants primarily consisted of older adults ( $>60$ years), as well as some middle-aged people and one 22 -year-old. Three women and six men were formally interviewed. A total of 20 informants are cited in compiled interviews and field notes. Interviews, workshops, and participant observation were all conducted in Bislama, which I was still learning at the onset of fieldwork. A Bislama translator verified my translations of the interviews while listening to audio recordings. Pseudonyms are used in this text to protect the identity of sources.

In interviews and informal conversation, informants noted my outsider status as a white visitor. My positionality as an American national connoted wealth and education, whereas my status as a young woman and student researcher made me appear less authoritative on my topic of study. Overall, I believe my status as an outsider allowed me increased access to leaders of Marou village and facilitated my research. I established initial contact with leadership in Emau through colleagues, who are conducting paleoclimate fieldwork on Emau, from the United States (at Woods Hole Oceanographic Institution) and at the University of South Pacific Emalus Campus in Port Vila. The field site was chosen for its close proximity to Port Vila and because it is the location of ongoing climate change research.

\section{Beyond vulnerability and resilience}

Results are divided into two sections. The first considers informants' perceptions of changing environmental baselines and various contextual socio-economic processes on Emau. The 
second section considers four response strategies that informants are currently deploying or hope to use to maintain and remain on the low-lying peninsula. Through this discussion, vulnerability and resilience emerge in various interrelated forms.

\subsection{Perceptions: Identifying and contextualizing climate change}

Many informants on Emau expressed fear for their physical safety living on the low-lying peninsula, which is often flooded by storm surges during cyclones. Compounding this anxiety are observed environmental changes, including droughts, fishery decline, and coastal erosion. Not all of these environmental hazards are new, but contemporary socio-economic challenges are exacerbating their negative effects.

\subsubsection{Sea level rise, erosion and vegetation die-off}

Evidence of sea level rise is ubiquitous. Informants use landmarks to mark shifting high tide marks. For example, Joseph, a 66-year-old male community leader, noted that a sandy area about three meters offshore at the end of the peninsula has completely eroded in the past few years, now "drowned." Metak, a male 78-year-old community and church leader, said that the water never reached the black stone path at the northern end of the lagoon, but the path now floods at every high tide. Nanette, a 45-year-old female journalist who lives in Port Vila but maintains ties with Marou, where she was raised, also observed extreme high tides:

Nanette: Last year [2017], like every December, we came and stayed here for Christmas. We found that the tide came so far up the shore that it reached the houses. The people who live in the village said something like that had never happened before. The water here [at the lagoon] is rising, and the water on the ocean side is rising too.

Multiple informants said that sea level rise has caused erosion along the coast. Large trees along the edges of the peninsula have recently died. Mangroves within the lagoon have also disappeared. Informants expressed feelings of anxiety, sadness, and regret about witnessing coastal vegetation die off:

Metak: Before, our village was lovely. It looked so, so nice. But then these changes started happening. Sea level rise-it started in the 1990s. Not '90, but maybe '97, '98. Since then until now, 2018, we have seen a big change in sea level... The sea is digging out the ground, making the ground go into the sea. And we can no longer build on spots where the bubu [our ancestors] built their houses. Yes, sea level rise is a big threat for us. It ruined the end of the peninsula. The sea carried away trees there, and it continues to cut away what used to be dry ground. The sea level rise situation is awful.

Joseph: Near the entrance over there, when you come inside the lagoon - at low tide, you can see a heap of black stones. But the bubu and our fathers told us that there used to be trees, coconuts, bush there. It used to be bush. But no longer. That's a change. That's a big change. 
Kalo (a 70-year-old male, who used to teach primary school on Emau before retiring): Since we were little, we have observed the trees near the sea. They fell down. Many of them used to grow near the end of the village, but they fell down. They died out.
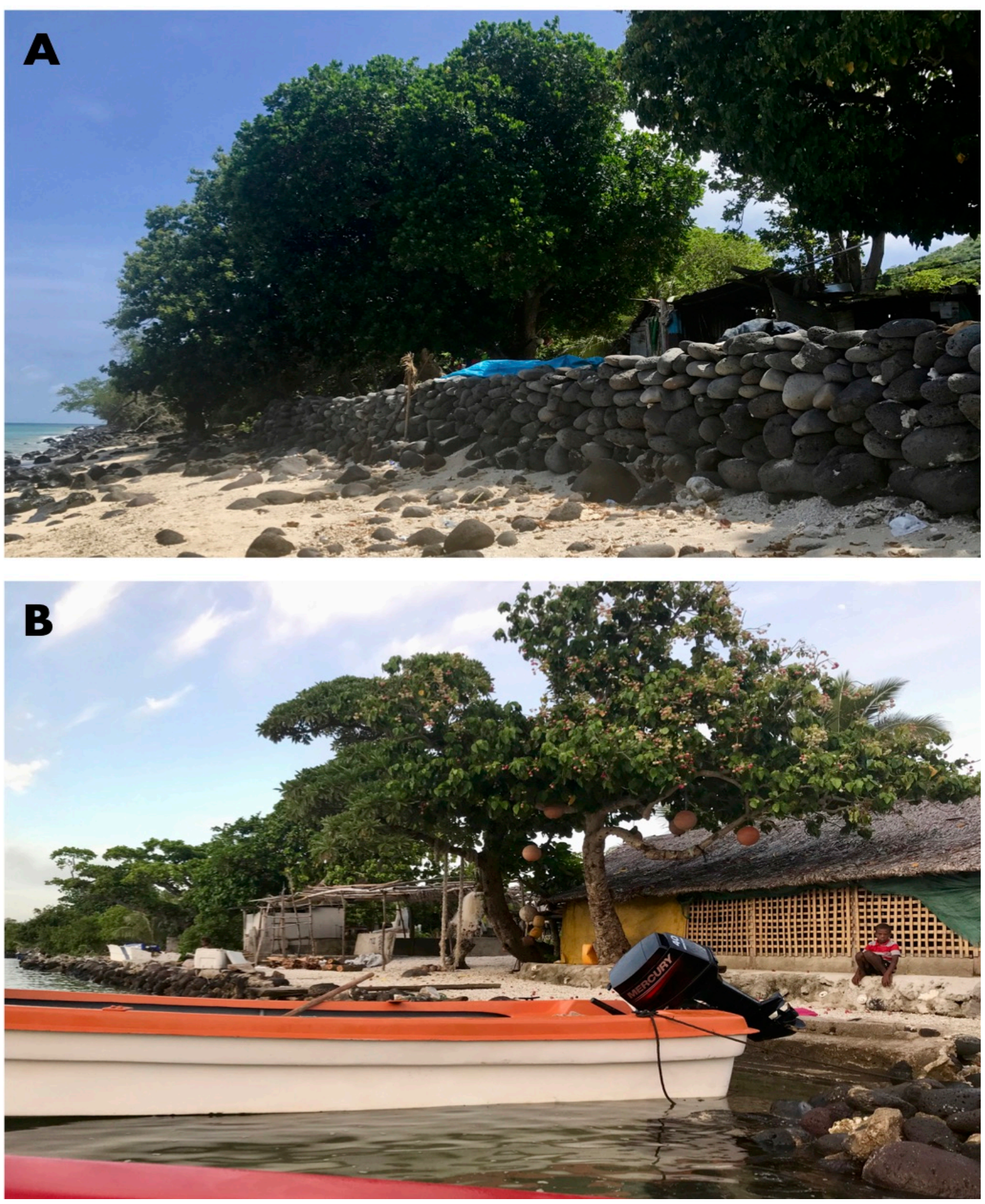

Figure 3. (a) Sea wall on the peninsula's ocean side at low tide. These walls, constructed of volcanic stones from Emau, are seen as flimsy solutions to sea level rise. At high tide, waves break against the sea wall, just a few meters from homes. (b) At high tide, the lagoon's waters encroach on coastal homes. Source: Sophie Ruehr. 
Sea level rise and coastal erosion are augmented by other recent perceived changes in the environment. Informants said the coral reef has died along the coast; soil erosion uphill has intensified (as evidenced by landslides); and fish stocks are dwindling.

\subsubsection{Water scarcity}

Water scarcity is another pressing concern in Marou. There is no reliable source of groundwater on the island, and the people of Marou rely exclusively on rainwater collected in several large storage tanks. The majority of tanks, which are costly to install (about 300,000 Vatu, or $\$ 2,800$ USD, per tank), were donated by aid agencies. There is also a freshwater stream that runs directly into the salty lagoon, and Joseph explained that people can use the brackish mix for cooking if needed.

After a month without rain, the reserves in the water tanks dwindle. If the tanks run completely dry, villagers must travel to mainland Efate to purchase water. This is costly, as residents must pay for both the water itself and transport to and from Efate. Therefore, access to water in times of scarcity falls along economic lines. Kalo and his nephew, Michael (a 40year-old male civil servant), agreed during a conversation that water scarcity is a looming issue for the village despite the water tanks:

Kalo: [A Peace Corps volunteer] helped us to build the water tanks here.

Michael: Now there's more water. But climate change is affecting us. It can't stop. It won't stop.

Kalo: Yes, we must bring water from Efate.

Michael: Now if we don't have water, people travel. What makes it very expensive is the transport costs.

Kalo: Boats. The transport cost-

Michael: People who don't have enough money don't drink water.

Kalo: They don't drink water. There are many people like that here.

Sophie Ruehr: But do they get sick? If they can't drink. . .

Michael: Yes, they get sick.

Kalo: Yes, they get sick.

Informants contradicted each other when asked whether drought is a new problem. Some informants attribute water shortages to climate change. Some say the shortages are due to population growth. Others believe water scarcity is a result of both factors. 
Metak, who is 78 years old, described a shift in rain patterns before and after 2001 . Although he attributed water shortages to both population growth and less rain in recent years, Metak thinks drought is primarily a result of climate change:

Metak: Here's something that's a problem for us, and I think it will be a bigger problem in the future: we don't have rain. We don't have a spring. We depend only on rainwater... Before, it wasn't like this. We did not have water shortages because there was not a large population. With the new millennium in 2000, there was a new problem because... I'm not sure, maybe it was climate change, which causes El Niño. There was a lot of sun [drought] and less rain. But before, it wasn't like this... Before there was lots of rain, which allowed us to have plenty of food. There was rain, and sun, and they cooperated together in the past. Our gardens bore us plenty of good food... Before, there was rain, rain, rain, rain, as I already told you. But these days, there is this problem of climate change. There is less rain.

45-year-old Nanette believes drought is the most serious problem facing Marou today. However, she sees water scarcity as an issue that has affected the community for decades and is not necessarily due to recent climate change or population growth:

Nanette: I don't know if it was happening before... A few months ago, when I was here, there was a water shortage. But I think that's been a problem for a long time already, water shortages.

A number of people left Emau and moved to Tagara, a village opposite Emau on mainland Efate, in the 1980s due to water shortages, suggesting that water scarcity has been an issue for at least three decades. Furthermore, a kastom story of fire on Emau may relate to a period of intense drought, suggesting drought may have actually affected Emau for centuries. Joseph told me this story in hushed tones, implying that it is confidential knowledge therefore, I will not disclose specifics of the narrative here. Outside sources (D'Aubert \& Nunn, 2010) have also recorded droughts persisting in the South Pacific for centuries. In section 4.2.2 below, I argue that attributing drought to climate change constitutes a deliberate strategy to leverage international attention and funding.

\subsubsection{Contextualizing climate change}

Challenges wrought by changing environmental baselines are exacerbated by a growing population, loss of traditional knowledge, and a dearth of steady cash flows into Marou. The following discussion explores socio-political and economic factors that condition Marou's adaptation strategies.

First, informants cited population growth as a major strain on resources. The population of Marou village was approximately 100 in 1990. Since then, the population has expanded to almost 300, despite many families' having moved to Port Vila. Joseph blamed the increase in population for some observed environmental changes:

Joseph: Before, turtles laid eggs here. They came, buried their eggs and then left. But now, they don't come often because, I think, the population is growing. There's 
too much noise, kids, people walking about, so [turtles] can't come lay their eggs here anymore.

Informants said that population growth has also increased strain on limited village resources, like water, housing and education.

Secondly, evolving conceptions of identity and kastom undermine traditional environmental resiliency strategies. Kastom knowledge, including agricultural practices and reading the landscape for signs of incoming weather systems, has historically helped the community prepare for, survive, and recover from natural hazards, like cyclones. But some informants worry that younger generations are overly exposed to foreign values, and kastom traditions and stories are not being passed down to younger generations. Metak said many people have forgotten the stories of the bubu (ancestors) because parents do not believe it is important to share these stories, and children are not interested. Diminishing interest in kastom knowledge is also documented in language choice. Young children prefer to speak Bislama over Emau's native language. Concerns that kastom knowledge, which has historically been a source of community cohesion and resilience to environmental stress, is not being passed on to younger generations was also recorded by Warrick (2011), and Kraemer (2020) found young people in Port Vila view the city as their primary place of belonging over their parents' home islands.

Religion is also to blame for cultural loss. As a ni-Vanuatu man once told missionary John G. Paton, Christianity "condemns the things we delight in" (MacClancy, 1981, p. 76). Similarly, Metak said religion and kastom "are enemies" as he held up his hands backwards to each other (as opposed to hands intertwined in prayer). Indeed, decades of colonial rule and missionary influence resulted in widespread denigration of traditional Ni-Vanuatu fasin (cultural codes and behaviors), while the bubu were seen as "backwards" and sinful, Joseph said. Past generations abandoned kastom behaviors to 'elevate' themselves from the "dark times" of the bubu.

A final challenge is access to cash incomes. Many informants expressed interest in relocating the village uphill. However, building new homes has substantial associated financial costs, and there are few opportunities to secure cash income on Emau. Although Nanette suggested that the community make an effort to return to traditional building styles - using local materials like palm fronds and bamboo in construction - the majority of informants emphasized the need for cash to buy imported, durable materials (like tin and concrete) before relocating, underscoring the prevailing problem of cash flow.

\subsection{Land guardians}

Despite its hazards, the low-lying peninsula is not readily abandoned. Informants expressed deep attachments to the peninsula and coastal lagoon. Kastom stories emphasize the lagoon's power - a spirit who lives in the lagoon's depths that can drown any person who attempts to dive deep below its surface or lower objects into its waters. The lagoon is also sentient, having once walked from the crater on top of the mountain to where it lives today. These narratives are widely known and appreciated throughout the community, documenting the lagoon's prominent role in cultural heritage and identity. The peninsula, home to important cultural and historic sites, is also a record of Marou's past. The village cemetery is located on the southern half of the peninsula, just feet above sea level, and was created soon after the first 
missionary was accepted in the village, between 1872 and 1876. Photos of loved ones who recently passed and the markings of more distant ancestors remind community members of their long attachment to this land. Leaving the peninsula would mean abandoning these sacred and sentimental spots, inspiration of stories and sites of memories.

Beyond their attachment to the peninsula and lagoon, relocating uphill would also affect residents' lifestyle and access to the water. Multiple informants expressed gratitude for living so near the sea: "We're a lucky island. We're lucky because the sea is right here. We must swim in the sea because it's God's gift to us," Joseph said. During a church service, Sarah, a middle-aged nurse and the adopted daughter of Metak, thanked God specifically for access to the lagoon. "Thank you for the beautiful lagoon," she said in prayer. Children play in the lagoon's shallow, calm waters. Residents use the sea to bathe. The coral reef and lagoon provide food from fishing and aquaculture activities. Relocating would limit this accessibility.

The following sections explore four strategies informants described to either stay in place on the peninsula or relocate uphill on their own terms - maintaining access to the peninsula and continuing to guard the low-lying land against rising waters.

\subsubsection{Labor migration}

As discussed above in section 4.1.3, there are few opportunities to attain steady cash incomes on Emau. Yet building homes uphill, away from the rising sea, with imported goods, like concrete and tin, requires financial capital. Historically, Emau residents have migrated to Port Vila and farther afield in search of work. The first of these migrations began when 'blackbirders' arrived in the mid-1800s, kidnapping Emau residents to labor against their will in Queensland (Mortensen, 2000), a history that informants (Kalo, Michael, Metak) retell today. Other informants have worked away from home more recently. Metak's younger brother went to New Caledonia in 1960 to mine nickel; Metak himself lived in Santo, an island in northern Vanuatu, collecting copra (roasted coconut) in the 1970s. Many families live divided between Port Vila and Emau, making monthly trips back and forth to visit. Migration is not new to the people of Emau.

In recent years, seasonal worker programs - in which $\mathrm{Ni}$-Vanuatu travel to $\mathrm{New}$ Zealand and Australia for up to 10 months to work on farms - have gained popularity, despite concerns over employee exploitation (Bailey, 2009). Individuals often participate in these schemes over multiple years and send remittances home. All of the families that have built new houses uphill (11 in total) have done so with funds from the schemes. But seasonal worker schemes also have their downsides: family members' disappearing for long periods of time each year leaves children without parents and caregivers without support. Joseph, Metak, and Nanette all agreed that the large portion of the population absent for more than half the year is leading to marriages' "falling apart" and undermines kastom practices. Informants also confirmed the prevalence of worker exploitation abroad.

Cash itself connotes its own set of challenges. Informants highlighted that money runs counter to kastom and undermines traditional value systems. One conversation in particular illuminated the complexities of cash: 
Kalo: The seasonal workers make a lot of money.

Michael: When they come back, they build houses. It's good that the government opened this scheme. We can build well [uphill]. But when there's money, our traditional ways halt. When you use your technology, waet man's [foreign] technology, it's okay. But I think that it doesn't suit this place...

While cash is necessary to build homes uphill, it also requires community members to leave Emau for long periods of time. Both the inflow of cash and outflow of people undermine kastom. This double bind is troubling, especially as most informants said seeking cash incomes away from the island was crucial to adaptation strategies. The need to accommodate a globalized capitalist system, despite documented worker exploitation and negative socio-cultural consequences, highlights the flaws in emphasizing material improvements in living conditions via economic growth over challenging unequal power relations and retaining cultural knowledge (Kumi et al., 2014).

\subsubsection{Leveraging 'development' aid, foreign expertise, and tourism}

Informants expressed strong interest in securing resources from external actors. Although Hau'ofa (1994) warns against continued reliance on foreign aid, these requests are made strategically. Informants envision a future in which the community retains ultimate authority over decision-making. Many informants requested outsider assistance, in the form of funding or volunteers, when asked about potential solutions to perceived environmental changes. Michael discussed various volunteers who have come to Emau and his hope that another may return:

Michael: I think you're the fourth person - I can't remember well. They come, they go... If American Peace Corps volunteers came here, they could help us resolve these problems. We want to host an American now. One came, but he already went back. We don't have one now... We want another one like him, like you, for climate change. We have a position for them. We need someone to come here and direct a committee or something.

Kalo, Michael, Metak, and Adrina (Metak's wife and a community leader) specifically asked me to secure another Peace Corps volunteer to work on climate change, raise money for more water tanks, or publicize their story in the U.S. Informants perceived me as having access to institutions that coordinate aid funding or volunteer services and seized the opportunity to leverage this connection. Their requests also document that the community plans to control incoming external funding and labor, aligning it with their own visions for adaptation in Marou.

Furthermore, connecting observed environmental changes with the climate crisis represents another strategy to secure resources. As discussed above in section 4.1.2, the cause of water scarcity is contested. Some informants believe drought has been an issue for decades, whereas others attribute water scarcity to climate change. No matter the cause of drought, however, linking water scarcity with the international nature of climate change holds outside actors accountable, and implies they should pay. 
Several informants specifically highlighted the effects and international nature of climate change:

Metak: We depend only on rainwater... I'm not sure, maybe it was climate change, which causes El Niño. Before, there was rain, rain, rain, rain, as I already told you. But these days, there is this problem of climate change. There is less rain.

Joseph: We live, we die. Climate change is destroying our home, but we live, we stay. Here we live, we're born, and we die, and climate change is ruining our home. You all come here, and it's good that you come to visit us. You come to see. We can show you the [climate change] effects of where you come from.

Kalo: If [foreign scientists] come here, we will tell them how the island has changed and how changes are taking place on the coastline.

Michael: Climate change is affecting us. It can't stop. It won't stop.

Informants said they would use external funding to build tourist infrastructure on the peninsula. This investment would create incentive to maintain the low-lying land. Simultaneously, the community would receive cash income to build safer homes uphill. Metak hopes the village can rebuild several bungalows, which were destroyed in Cyclone Pam (the second-most powerful cyclone to develop in the Pacific, which traveled directly over Emau in 2016), and add a footpath for hikers to the top of the mountain. Both he and Adrina said that the beach would entice honeymooning couples or wedding ceremonies, and Metak also requested that I write an online promotion for a day trip in Marou. Joseph added that tourism could improve the standard of living in Marou by generating income. Although the community would no longer inhabit the peninsula full time, continuing community investment in and engagement with the peninsula via tourism infrastructure would enable informants to preserve their connection to the land.

Joseph's comments on tourism hint both at tourism's potential benefits and unintended consequences.

Joseph: There are some people in the world today that God gives white skin. And they have knowledge. They know more... They can make businesses here. We can leave our houses [on the peninsula] and move to the other side [uphill]. It's an idea of mine. The beach over there-investors could develop it for a good profit. I'm an old man. I don't like money. I like my food, my manioc [a root vegetable], my shirts. I have enough shirts. But there's a vision of the future if you want it. If a tsunami comes, every one of us will die. It's not good. We need to go to the safe side [uphill]. We can help friends from the outside world to start tourism businesses here.

Joseph believes tourism infrastructure would allow his community to move to safer homes uphill. However, his comments also reveal troubling dynamics, including power imbalances between foreign investors and community members. 


\subsubsection{Revitalizing kastom}

In reaction to events like Cyclone Pam and observed environmental changes, some informants suggested the village should return to kastom methods of mitigating environmental stress. Kastom knowledge addresses agricultural and food storage practices, building material sourcing, and reading the landscape for signs of changing seasons and weather systems. Informants who are concerned with cultural loss believe reviving kastom practices may also improve community cohesion. Metak explained that people should not forget kastom beliefs, which are hugely important to the village's history and future: "[We] must hold on tight" to the beliefs of the bubu, he said. "It's kastom. It's important," Adrina agreed.

Nanette gave an example of kastom knowledge that would be useful in the face of the climate crisis: using locally sourced building materials.

Nanette: I think we will have to go back to the traditional ways of building strong houses. To my knowledge, in the past the bubu used local [materials to build] houses that could withstand strong winds during cyclones. We must return to the ways of the past-constructing houses prepared to face strong cyclones... Before, the bubu built houses with only local [materials], and when they knew a cyclone was coming, they would go to the bush. They would get coconut fronds and fasten the ends of the fronds with rope to the roofs of their houses so that the wind could not blow the roofs off.

Here, Nanette suggests that the construction methods of the bubu were better suited to resist cyclones than building 'Western-style' houses with imported goods. In the past, the people of Emau would use only local materials, like coconut fronds and bamboo, to build cyclone houses, which were round, without large openings, and close to the ground. Although these structures required frequent maintenance, they were more resilient to winds, flexing instead of breaking against the force of cyclone gales, she explained. Using local materials would also relieve some of the stress around cash incomes in the community.

Examples of maintaining kastom already exist on Emau. Although, as one informant pointed out, Christianity and kastom are inherently at odds, hybrid formations of internal and outsider influences can also preserve traditional culture within a constantly evolving global context (Baldacchino, 2008). One example of such hybridity on Emau is the Five-Day Feast, held five days after a death. The feast brings together communities, tied by kin relations, from Emau and its neighboring islands to celebrate the life of the departed. I attended one FiveDay Feast on my second visit to Emau. Over several hours, each community in attendance presented an offering of food, which was divided equally into piles. A jif (community leader) then walked to each pile and announced the village to which the food belonged (see Figure 4). This ritual, Adrina and a pastor attending the ceremony explained to me, derives from an ancient practice of the bubu. Nevertheless, the pastor recited a Christian prayer to close the ceremony. 


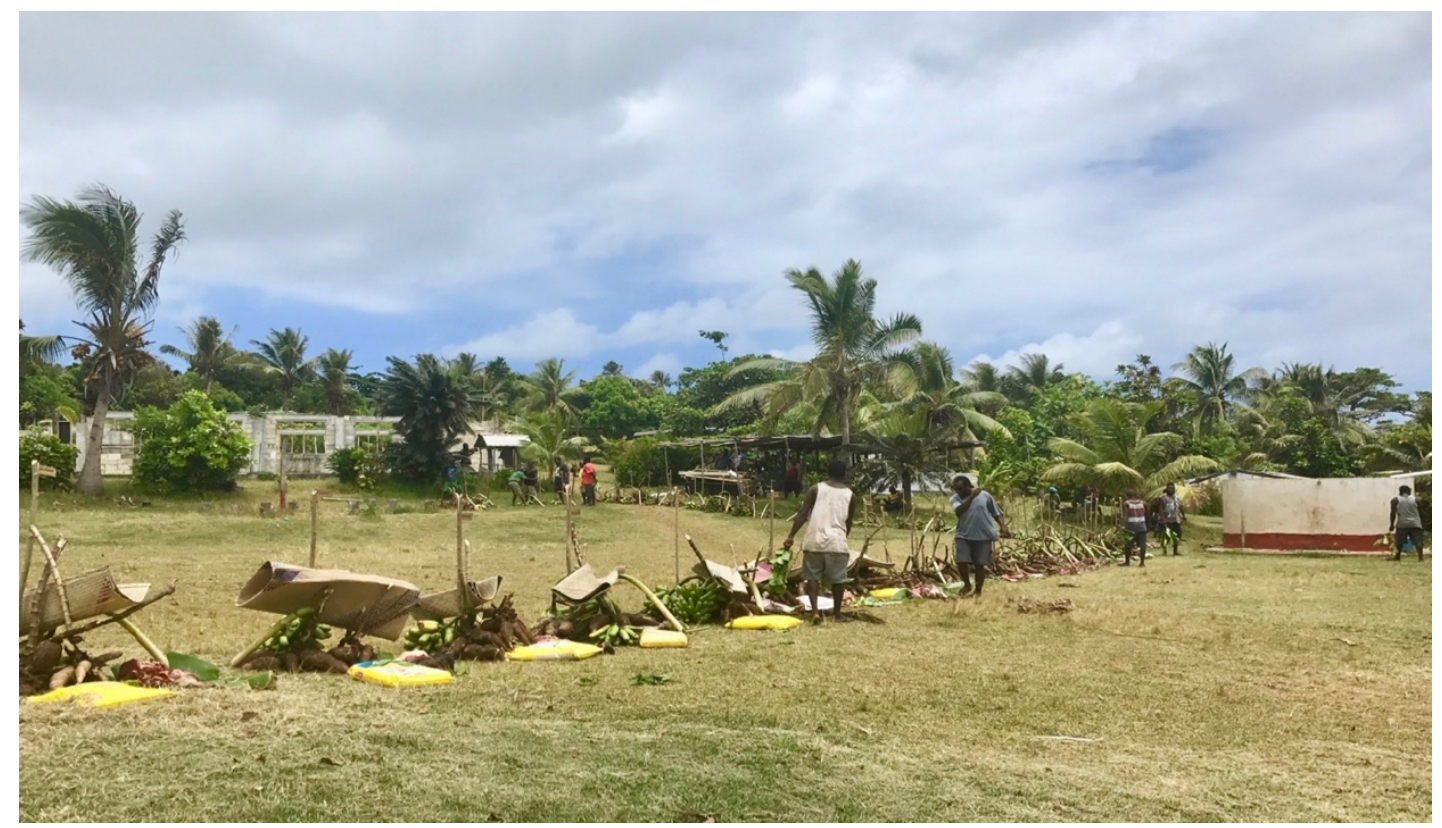

Figure 4. Five Day Feast ceremony. Offerings of food (including plantains, bags of rice [yellow], manioc, yams, and meat) are divided equally into piles, marked with a stick, for each community in attendance. A jif (orange shirt, background) walks to each pile, announcing the name of the community to which the pile belongs. Source: Sophie Ruehr.

By combining kastom and Christianity, the Five-Day Feast has absorbed and been transformed by Western religion, allowing contradicting paradigms to coexist coherently. The celebration is a form of environmental resilience - during a period of difficulty, communities pool resources. Hybrid forms incorporate both traditional and outsider paradigms, in this case maintaining kastom by inscribing it within contemporary religious practice.

Other examples of hybridity occur on a daily basis. At a church service, Informant 5 reminded the congregation to remember both their faith and kastom in their everyday lives. Although inherently at odds, these formations are internally coherent to informants, who have morphed traditional practices into popular contemporary frameworks, thereby celebrating and maintaining the old within the new (Douglas, 1998). Continuing to rely on hybridity to preserve the benefits of kastom knowledge may represent another strategy to manage changing environmental baselines.

\subsubsection{Physical and emotional labor}

Sea level rise, storm surges, erosion, and water scarcity have all contributed to a sense of anxiety in Marou; informants know that their homes and lives are at risk if they continue to live on the low-lying peninsula. Tsunamis are also a concern (there are no tsunami warning systems installed in Efate's offshore islands). On three separate occasions, Metak said that the peninsula is "denja tumas"—very dangerous—and others (Julie, Nanette, Adrina) echoed this sentiment.

Yet, the community persists in its efforts to preserve the peninsula and remain in place. A variety of ongoing projects document efforts to mitigate erosion through physical infrastructure. Village leadership has created a conservation area from which no timber or rocks can be collected for construction, with the goal of managing erosion and mitigating sea level rise. The community has also built about a half-kilometer of sea walls, one meter high, 
along the ocean and lagoon shores (see Figure 3a) to prevent flooding at high tides. Individuals (for example, Metak's son) have planted and tended to coral gardens in an attempt to regrow the reef on the ocean side, with some success. Healthy coral reefs have been shown to mitigate the effects of rising seas (Beetham et al., 2017). Other informants have planted grass uphill to decrease the risk of landslides and mangroves in the lagoon to forestall erosion. Some of these efforts were initially introduced by outsider development programs like REDD+.

Beyond these physical infrastructure improvements, informants also perform emotional labor to remain on the peninsula. Constantly managing concerns about the threat of flood and drought is challenging, and several informants said that they experienced a period of intense sadness after Cyclone Pam hit the island in 2016.

The emotional toll of living on the peninsula is partially addressed through prayer. Metak described a new movement that empowers him to confront the climate crisis.

Field notes: Metak told me about the Healing the Land movement, which brings people together to reconcile differences, pray and bless the land. Healing the Land is based on a Biblical verse, which teaches that if people seek God and see his face, they will be blessed, and their land will be healed. People put "element water" onto their trees, land and plants to bear better fruit, to heal and to become stronger. He also said that no person, including scientists, knows how to stop climate change. But God does. If God made tsunamis, earthquakes, the sea and cyclones, he also knows how to stop them. The only way to stop climate change, therefore, is by praying to God.

Prayer is a historic form of resistance in Vanuatu. Christianity was used as a tool for nation-building, bringing together the population under one moral code, and the first black pastors are still remembered and celebrated today as symbols of resistance to colonial rule and empowerment (Eriksen, 2009). Throughout my stay on Emau, my hosts emphasized the universal love towards all humanity they felt through their faith. Since prayer represents political power and community cohesion, turning to religion represents yet another strategy in climate change adaptation. Feeling hopeful despite observed environmental changes is a form of emotional labor that allows families to continue to live on the peninsula.

Some families have even chosen to build new houses on the peninsula despite the danger. Metak was skeptical of this choice, saying residents were "crazy" because they refused to "look to the future." Michael agreed, saying that those families had been nearsighted in refusing to move. "They are like Saint Thomas," requiring tangible contact with danger before realizing the threat, he said. Informants' determination to remain in place implies a deliberate effort to manage anxiety about their safety and a 'voluntary immobility' in the face of climate change (Farbotko \& McMichael, 2019, p. 149).

\section{Conclusions}

On Emau, the effects of the climate crisis, including sea level rise, intensifying cyclones, and drought, have been noted to varying degrees by informants. In responding to a changing environment, the community is pursuing several overlapping strategies, which are conditioned by contextual elements such as population growth, limited access to cash incomes, and cultural loss. These strategies include: 1) building infrastructure and houses 
uphill with monies earned working abroad or in Port Vila; 2) leveraging international aid and development funding to pursue visions of the future, including tourism industry development; 3) creating hybrid forms that inscribe traditional environmental knowledge within contemporary religious practice, which ultimately preserves this knowledge; and 4) performing physical and emotional labor to maintain and remain on the peninsula. These strategies highlight a range of mobilities, extending over a range of scales, from across the Pacific to across a lagoon.

The terms vulnerability and resilience begin to lose meaning when situated in context. Drought suggests vulnerability. But by linking drought to climate change, informants hold outside actors accountable, a move that represents a strategic leveraging of resources. Religion both undermines and maintains kastom knowledge. Labor migration allows families to move to higher ground while weakening social cohesion. Tourism and international aid are welcomed but may pose risk to local ownership (Baldacchino, 2008). Even within a small community of 300 people, informants expressed a wide diversity of views regarding the causes of recent environmental changes and adaptation strategies. Some informants pointed out major downsides where others saw opportunity. This diversity challenges the vulnerability/resilience framework, which often obscures both power relations and ambiguity (Kelman, 2020). Attempting to map these strategies and concerns onto the vulnerability/resilience dichotomy would be a reduction of this complexity, and therefore a distortion of reality.

This study reveals the limitations of the resilience/vulnerability framework, which narrows issues faced by SIDS to climate-specific problems that can lead only to climatespecific solutions. Understanding the climate crisis through a different frameworkperception/response - better describes the diversity of islanders' relationships to the climate crisis. The perception/response framework centers islanders' rather than outsiders' visions of and solutions to climate change. It avoids passing value judgements. It brings power relations into sharper focus by moving away from dichotomies, which obfuscate complexity, and emphasizing the importance of contextual factors, like culture and religion, that shape individual and community understanding. Perception/response reveals how power operates by acknowledging contradictions emerging from diversities of opinion and experience.

Complexity does not lend itself to simple solutions. The perception/response framework does not offer easily glossed pictures of island communities, which may present challenges for those hoping to 'solve' the problem of climate change on islands. Indeed, tracking perceptions and responses to climate change may lead away the starting point, revealing more pressing concerns that appear less relevant to environmental change (Baldacchino, 2018). However, reductionist understandings should not be the aim of climate-related projects or research. Instead, emphasizing the experiences of islanders and island-derived adaptation strategies - in all their complexity - is both a practical goal and one that underscores the sovereignty and agency of islanders to define their own dreams for the future. Sustainable adaptation strategies are to be found in this nuance, not reductionism.

This study is clearly not a complete picture of the various processes and strategies currently unfolding on Emau. To expand upon this work, more rigorous oral history and anthropological methodologies need to be undertaken, including surveys, map-making, and workshops with segments of the population (women, youth, and disabled people) who are 
often left out of conversations or who redirect questions to men in leadership positions. Interviewing a wider array of informants would confirm details presented here.

Pacific island nations are on the front lines of the climate crisis. This does not mean, however, that they are inherently vulnerable to environmental change. Rather, they are innovators in adaptation and leaders of the climate justice movement. Instead of being small, vulnerable, and isolated, Emau, and Vanuatu more generally, is an ever-morphing matrix of connections, migrations, and receptions. It is the breeding ground of new ideas and hybrid formations that challenge reductionist narratives. Informants' relationships to climate change are inherently global, making islands hubs of constantly evolving perceptions and responses, negotiations, and collaborations.

Acknowledgements: This work was funded by Yale University's Parker Huang Research Fellowship. Professor Michael Dove, Dr. Krishna Kotra, and Nikita Perumal provided guidance and mentorship. S.B.R. and E.L.R. provided editorial feedback. Two anonymous reviewers provided thoughtful suggestions.

\section{References}

Bailey, R. (2009). Unfree labour? Ni-Vanuatu workers in New Zealand's Recognised Seasonal Employer Scheme [Doctoral dissertation, University of Canterbury]. UC Research Repository. https://ir.canterbury.ac.nz/handle/10092/2957

Baldacchino, G. (2018). Seizing history: Development and non-climate change in Small Island Developing States. International Journal of Climate Change Strategies and Management, 10(2), 217-228. https://doi.org/10.1108/IJCCSM-02-2017-0037

Baldacchino, G. (2008). Studying islands: On whose terms? Some Epistemological and methodological challenges to the pursuit of Island Studies. Island Studies Journal, 3(1), 37-56.

Beetham, E., Kench, P. S., \& Popinet, S. (2017). Future reef growth can mitigate physical impacts of sea-level rise on atoll islands. Earth's Future, 5(10), 1002-1014. https://doi.org/10.1002/2017EF000589

Bernard, H. R. (2006). Research methods in Anthropology: Qualitative and quantitative approaches ( $4^{\text {th }}$ ed.). Rowman Altamira.

Cameron, E. S. (2012). Securing Indigenous politics: A critique of the vulnerability and adaptation approach to the human dimensions of climate change in the Canadian Arctic. Global Environmental Change, 22(1), 103-114. https://doi.org/10.1016/j.gloenvcha.2011.11.004

Central Intelligence Agency. (2020). Vanuatu. The World Factbook. https://www.cia.gov/library/publications/the-world-factbook/geos/nh.html

D’Aubert, A., \& Nunn, P. D. (2010). Furious winds and parched islands: Tropical cyclones (15581970) and droughts (1722-1987) in the Pacific. Xlibris.

Douglas, B. (1998). Traditional individuals? Gendered negotiations of identity, Christianity and citizenship in Vanuatu. Australian National University.

Eriksen, A. (2009). 'New life': Pentecostalism as social critique in Vanuatu. Ethnos, 74(2), 175-198. https://doi.org/10.1080/00141840902940476 
Esteban, M., Jamero, Ma. L., Nurse, L., Yamamoto, L., Takagi, H., Thao, N. D., Mikami, T., Kench, P., Onuki, M., Nellas, A., Crichton, R., Valenzuela, V. P., et al. (2019). Adaptation to sea level rise on low coral islands: Lessons from recent events. Ocean $\mathcal{E}$ Coastal Management, 168, 35-40. https://doi.org/10.1016/j.ocecoaman.2018.10.031

Facey, E. E. (1988). Nguna voices: Text and culture from Central Vanuatu. University of Calgary Press.

Farbotko, C. (2010). Wishful sinking: Disappearing islands, climate refugees and cosmopolitan experimentation. Asia Pacific Viewpoint, 51(1), 47-60. https://doi.org/10.1111/j.1467-8373.2010.001413.x

Farbotko, C., \& Lazrus, H. (2012). The first climate refugees? Contesting global narratives of climate change in Tuvalu. Global Environmental Change, 22(2), 382-390. https://doi.org/10.1016/j.gloenvcha.2011.11.014

Farbotko, C., \& McMichael, C. (2019). Voluntary immobility and existential security in a changing climate in the Pacific. Asia Pacific Viewpoint, 60(2), 148-162. https://doi.org/10.1111/apv.12231

François, A., Franjieh, M., Lacrampe, S., \& Schnell, S. (2015). The exceptional linguistic density of Vanuatu. In A. François, S. Lacrampe, M. Frajieh, \& S. Schnell (Eds.), The languages of Vanuatu: Unity and diversity (pp. 1-21). Asia-Pacific Linguistics.

Hau'ofa, E. (1994). Our sea of islands. The Contemporary Pacific, 6(1), 148-161.

Hayward, P. (2012). Aquapelagos and aquapelagic assemblages: Towards an integrated study of island societies and marine environments. Shima, 6(1), 1-11.

Jamero, M. L., Onuki, M., Esteban, M., Billones-Sensano, X. K., Tan, N., Nellas, A., Takagi, H., Thao, N. D., \& Valenzuela, V. P. (2017). Small-island communities in the Philippines prefer local measures to relocation in response to sea-level rise. Nature Climate Change, 7(8), 581-586. https://doi.org/10.1038/nclimate3344

Karides, M. (2017). Why island feminism? Shima, 11(1), 30-39. https://doi.org/10.21463/shima.11.1.06

Kelman, I. (2020). Islands of vulnerability and resilience: Manufactured stereotypes? Area, 52(1), 6-13. https://doi.org/10.1111/area.12457

Kraemer, D. (2020). Planting roots, making place: Urban autochthony in Port Vila Vanuatu. Oceania, 90(1), 40-54. https://doi.org/10.1002/ocea.5239

Kumi, E., Arhin, A. A., \& Yeboah, T. (2014). Can post-2015 sustainable development goals survive neoliberalism? A critical examination of the sustainable developmentneoliberalism nexus in developing countries. Environment, Development and Sustainability, 16(3), 539-554. https://doi.org/10.1007/s10668-013-9492-7

Li, T. M. (2014). Anthropological engagements with development. Anthropologie \& Développement, 37-38-39, 227-240.

MacClancy, J. (1981). To kill a bird with two stones: A short history of Vanuatu. Vanuatu Cultural Centre.

Manuel-Navarrete, D. (2010). Power, realism, and the ideal of human emancipation in a climate of change. Wiley Interdisciplinary Reviews: Climate Change, 1(6), 781-785. https://doi.org/10.1002/wcc.87

Mortensen, R. (2000). Slaving in Australian courts: Blackbirding cases, 1869-1871. Journal of South Pacific Law, 4, 7-37. 
Perumal, N. (2018). "The place where I live is where I belong": Community perspectives on climate change and climate-related migration in the Pacific island nation of Vanuatu. Island Studies Journal, 13(1), 45-64. https://doi.org/10.24043/isj.50

Simo, J., \& Naupa, A. (2005). Report of the national review of the Customary Land Tribunal program in Vanuatu. Vanuatu National Cultural Council.

Vaioleti, T. M. (2006). Talanoa research methodology: A developing position on Pacific research. Waikato Journal of Education, 12, 21-34.

Varrall, M. (2019, February 8). Chinese assistance and loans [Conference presentation]. The China Alternative, University of the South Pacific Emalus Campus, Vanuatu.

Vitousek, S., Barnard, P. L., Fletcher, C. H., Frazer, N., Erikson, L., \& Storlazzi, C. D. (2017). Doubling of coastal flooding frequency within decades due to sea-level rise. Scientific Reports, 7(1), 1-9. https://doi.org/10.1038/s41598-017-01362-7

Walshe, R., \& Stancioff, C. (2018). Small island perspectives on climate change. Island Studies Journal, 13(1), 13-24. https://doi.org/10.24043/isj.56

Warrick, O. (2011). Local voices, local choices? Vulnerability to climate change and community-based adaptation in rural Vanuatu [Doctoral dissertation, University of Waikato]. University of Waikato Research Commons.

Warrick, O. (2009). Ethics and methods in research for community-based adaptation: Reflections from rural Vanuatu. Participatory Learning and Action, 60, 76-87.

Westoby, R., McNamara, K. E., Kumar, R., \& Nunn, P. D. (2020). From community-based to locally led adaptation: Evidence from Vanuatu. Ambio, 49(9), 1466-1473. https://doi.org/10.1007/s13280-019-01294-8 